\title{
Drought: Opportunities for Impact Mitigation
}

\begin{abstract}
Drought is an ancient natural hazard that has probably killed more people than any other. It is difficult to mark the start and end of drought because the moisture deficit develops slowly over weeks, months, or years. Atmospheric scientists can neither forecast nor control drought. Drought mitigation must focus on reducing the underlying physical and social vulnerability. Short-term adjustments do not yield a lasting adaptation to drought. Some argue that repetitive food aid may worsen long-term food-production problems and land degradation by deferring more fundamental adjustments. Decisionmakers need better information and a broader range of adjustment options in order to reduce drought vulnerability. A linking of global warming/climate change studies with drought studies can yield insights into how societies might deal with climate change and help define the potential for future drought. (Ed.)
\end{abstract}

\section{Drought threatens the sustainability of the natural resource base on which society depends.}

\section{Introduction}

Drought is an ancient natural hazard, though its effects on society have been exacerbated in recent decades by the growing vulnerability of some groups, regions, and resource-management systems. Drought, and the famine it engenders, has probably killed more people than any other natural hazard. Thousands died from the drought and famine that swept India in 1965 and 1967. While India was effectively reducing its drought vulnerability through food banks and rural development programs in the 1970s (Sinha and others, 1987), the African Sahel entered a multidecade episode in which drought and heightened social vulnerability ultimately killed millions of people in one of the most drastic reversals of regional development in modern times (Kates, 1981; Glantz, 1987: Timberlake, 1985).

Drought impacts, of course, are not restricted to the less developed regions: in 1988, the USA experienced one of the driest years of the century, causing a 31 -percent reduction in that country's normally quite reliable small grains production. The drought tested the resilience of resource-management systems throughout the country; some were prepared and flexible, others were too aged, rigid, or simply inadequate to cope (Riebsame and others, 1991). Identifying this difference in advance is the key to reducing drought vulnerability.

\section{Symptoms of Drought Vulnerability}

When the rains fail, temperatures soar, and drying winds blow-as occurs inevitably in most parts of the world - the "normal" pattern of crop growth. grassland productivity, and water supply is disrupted. Self-provisioning farmers and pastoralists go hungry or must migrate, commercial farmers watch their profits and family well-being wither. village wells dry up, urban water systems fail, livestock deteriorate and die, the poor and elderly - in substandard housing or no housing at all-die in cities that become heat traps, and the forests and scrublands burn with a ferocity unfamiliar to wildfire analysts.

Many of these symptoms were observed in the United States in 1988, as they were in Australia during 1983 (Allan and Heathcote, 1987), Europe in 1976 (National Water Council, 1977), Brazil in 1972 (Garcia, 1981), and in northern Africa throughout the $1970 \mathrm{~s}$ (Glantz 1987). The anomalous lack of rain is a root climate cause of drought, but the concept of drought also refers to reduced soil moisture, groundwater, and the general desiccation of natural and managed systems. On the heels of these first-order effects follow crop failure, famine, wildfires, soil erosion and salinization, regional desertification, and the forced migration of people and animals. More than any other natural hazard, drought threatens the sustainability of the natural resource base on which society depends.

\section{The Drought Hazard}

Drought is perhaps unique in its range through all geographical zones. Indeed, only in the driest deserts, where rain may not fall for months or even years, or at the Poles, can we say that drought does not occur. Everywhere else, from the tropical islands of the Caribbean. to normally moist European. Asian, or South American forests. drought occasionally erupts to affect agriculture, water supply, energy production, industry, wildlife and natural preserves, environmental quality, and urban services.

Drought is a creeping, pervasive natural hazard that develops over the course of weeks, months and years. The worst droughts occur when chronic dry and hot weather conditions, related to persistent anomalies in atmospheric circulation, cause a progressive desiccation of the land and ecosystems over seasons and years. Under the cumulative stress of drought, moisture is depleted from vegetation, soil, water bodies, and aquifers. The rainfall needed to bring natural resource systems back to "normal" may be more than the relative deficit which caused the drought initially. Thus, it is difficult to mark the start and end of drought - and a drought is not necessarily terminated simply by the return of "normal" rains.

Scientists can track the atmospheric circulation patterns that produce droughts (Rasmussen. 1987; Trenberth and others, 1988), and analysts follow drought development using various climatic indices that reflect cumulative rain or snow deficits, the moisture 
content of soils, groundwater. or vegetation, and the volume and flows of ground and surface waters (Wilhite and Glantz, 1985). Unfortunately, atmospheric scientists cannot forecast drought, nor can they control it. The persistent seasonal weather patterns that have caused droughts in both tropical and midlatitude areas over the past few decades can only be described after they have been established; they cannot be forecast the weeks or months in advance that would help resource managers prepare for drought (Hare 1987: p. 4-5). And there is not much hope for improved drought prediction in the next decade. The elaborate global atmospheric research projects of the $1960 \mathrm{~s}$ and 1970s, designed to provide reliable monthly and seasonal forecasts, failed in that quest and have been replaced by efforts to project global climate change instead, as the specter of the greenhouse effect attracts increasing public concern.

Finally, there are problems with the usability of drought indices. For example, the well-known Palmer Drought Severity Index (PDSI) must be examined carefully before it is used to infer drought stress on different elements of natural systems. The hydrological calculation used in the PDSI is more appropriate for long-term drought measurement and when the concern is over groundwater. The soil-moisture index is better suited to agricultural drought assessment, and the PDSI is simply not well suited to assessing vegetative drought or fire danger. Streamflow indices are more appropriate to surface-water drought assessment, and rainfall deficits may help to assess ecosystem effects. The bottom line, however, is that drought measures must be used with caution, especially if critical decisions are $\mathrm{to}$ be based on them.

\section{Drought Impacts and Mitigation}

Global loss to drought is unmeasurable, and the impacts are distributed disproportionately among groups and regions, falling especially on the least developed countries. For example, Kates (1980) estimated that annual drought costs in Tanzania during the 1970 s were 1.8 of that country's gross national product (GNP), while in Australia, which also experienced severe droughts, losses were more on the order of 0.10 of GNP. Moreover, drought losses can appear deceptively minor. A government task force concluded that the $\$ 39$ billion estimated direct losses associated with the 1988 drought in the USA caused little "national" reverberations, perhaps raising consumer prices by 0.1 percent (Interagency Drought Policy Committee. 1988). Yet, in one state, North Dakota, the drought caused a 15 percent loss of total business activity (Aakre and others, 1988). Moreover, if the drought did indeed cause direct losses of $\$ 39$ billion. then it was the worst single disaster in U.S. history - a year later Hurricane Hugo cost $\$ 9$ billion and the Loma Prieta earthquake near San Francisco caused roughly $\$ 6$ billion in direct losses. But, the repetitive loss from drought, which occurs in some part of the globe every year, cannot be measured or even estimated with any confidence. We know only that drought is among the most widespread, persistent, and pervasive natural hazards.

In the absence of reliable forecasts, drought mitigation must focus on reducing underlying physical and social vulnerability. Drought does not lend itself to emergency management measures; indeed, analysts have shown that hastily created drought-relief programs are inefficient, and often result in misdirected and wasted aid (Wilhite and others, 1986). Drought effects are more subtle than, say, the downed buildings of earthquakes or the devastation of a hurricane storm surge. Drought losses are more pervasively distributed across the natural and human landscape: a diminution of regional waterfowl habitat, reduced income for thousands of farm families, and higher food prices for all consumers.
Drought contingency plans are a common element of water. resources management, but less attention is paid to the coordinated management of food supply, soil conservation, or critical landscape features such as wetlands, to reduce future drought impacts. Ton often, effects of drought are dealt with by temporary adjustments and restrictions in water use. Even droughts that develop over months and years are treated as "emergencies" evoking an extraordinary. oftcn inefficient, patchwork of short-term solutions: food aid for drough refugees, emergency well drilling and water piping, payments is: farmers, and temporary water-use restrictions.

More than any other natural hazard
attracting world attention under the
IDNDR, drought offers the unique
opportunity to link natural hazard
reduction with concerns over global
environmental change. especially
climate warming.

Unfortunately, many of these shon-term adjustments do not yield more lasting adaptation to drought. Some analysts argue that repetitive food aid rarely solves, and may actually worsen. Iong-term food production or land degradation problems by deferring mote fundamental adjustment. Water-use restrictions in cities have little lasting effect unless incentives are provided for residents to reducc their long-term water needs by replacing water-loving landscaping or changing family water habits. Great success has been achieved in some areas along these lines: The State of California has actually reduced per capita domestic water consumption through long-tern conservation programs. But, this action came only after several severe droughts and as the region came under great political and economic pressure to solve its water problems. Few other parts of the developed world. although similarly sensitive to drought. have in plemented such far-reaching water use efficiencies-many areas in the western USA do not even meter residential water use.

The chief challenge of drought-hazard reduction in the nes! decade, then, is to build bridges between short-term responses and longer term mitigation.

\section{Growing Social Sensitivity?}

Losses from all types of natural hazards are growing globally not because the occurrence of extreme natural events is increasing. but because more people and more investments are at risk in hazard zones (Mitchell 1989; National Academy of Sciences. 1987: Rietsame and others, 1986). There is no evidence that drought has become more frequent in recent years. although the remarkable persistence of Sahelian drought is perhaps one of the most outstancing climate anomalies of the second half of the Twentieth Century (for example, Lamb, 1982). Instead. recent studies suggest that the global climate is generally becoming wetter, rather than drier, alon: with a slight warming over the past several decades (Diaz and others. 1989), which some scientists ascribe to anthropogenic global warm ing through the greenhouse effect.

Yet, a case can be made that in many areas the precipitation deficits that caused little significant impact in the past now result in great social disnuption. Physical drought itself is not changing, but 
iociety is changing the point at which a dry spell becomes a drought catastrophe. The same may be true for other natural hazards: little progress has been made in avoiding further development in floodplains, seismic zones, or sensitive semiarid regions. Thus, the loss from natural extremes increases without an increase in frequency of events. Population pressure, marginalization of poor people, and the need to go increasingly further afield for natural resources such as oil, water, and cropland, to support the global/urban economy, place more human activity at risk from hazards. Even where resource ystems were once adequate, neglect and decay have worsened drought impacts.

Of course, not all development patterns increase hazardousness. Liverman (1990) has shown that investment in irrigation, machinery, and fertilizers has reduced drought vulnerability in some areas of Mexico. Drought contingency planning in the southeastern U.S., following a dry spell in the early 1980 s, resulted in reduced losses in the severe 1988 drought (Riebsame and others, 1991). Yet, other regions, cut off from such improvements owing to economic, politisal. or geographical reasons, suffer more from each drought.

\section{Opportunities for Drought-Hazard Mitigation in the 1990s}

Drought, like other natural hazards, can be reduced by multiple approaches. We have attempted to reduce the physical event itself, through cloud seeding or other weather-modification technologies, to little avail. We regularly reduce drought's immediate impacts by protecting or moving people out of harm's way or by providing emergency water and food sources. Ultimately, however, droughtlike other natural hazards - is woven into the fabric of peoples interaction with natural resources and into the nature of regional development. Indeed, the failure of weather modification to prove itself as a reliable drought-management tool, and the marginal skill of seasonal climate forecasts, place pressure on hazard researchers and managers to deal with drought vulnerability as an inherent part of regional development-related to factors such as population growth, poverty, interactions between urban and agricultural economies, and aging infrastructure.

The opportunity in the 1990s, under the International Decade for Vatural Disaster Reduction (IDNDR) and other programs, is to reduce drought hazards through a constellation of methods rather than through any small set of fixes. Among the key approaches are:

Providing More Drought Information to Resource Managers.The key to drought-hazard reduction is information: prehazard information about drought, real-time information about the evolution of ongoing drought episodes, and information about alternative drought adjustments.

A particular need is for current climate, food, and water-supply information systems to be linked, regionally, nationally, and internaionally, into "drought-watch" systems that can inform decisionmakers when weather systems have established drought patterns and when drought indices suggest that natural resource systems are drying to the point where they will behave differently than in the past for example, well levels will decline, streamflow will be lower, and fires will be larger and hotter).

Institutions, such as the International Drought Information Center at the University of Nebraska, can play a key role in such a drought-watch system, as would an integration of resource and environmental monitoring programs run by the World Meteorological Organization (WMO), UN Environment Program (UNEP), and UN Food and Agriculture Organization (FAO), especially the Famine Early Warning System-FEWS - (McIntire, 1987).
Widening and enriching the range of options. - Decisionmakers at all levels need a broader range of adjustment options from which to choose in reducing drought vulnerability. As environmental advocates and the general public become less tolerant of large structural systems for water management and of the negative effects of highinput, intensive agriculture, alternatives that enhance the resiliency of current systems and that incorporate local/regional solutions unique to particular settings must be sought. There is no universal prescription for drought-hazard reduction, but good examples exist, and a first step toward a more comprehensive mitigation would be to gather and examine the good examples and to describe the range of options being applied. Next, options must be carefully transferred in appropriate ways. What worked in the US and Canada may not be appropriate to Zimbabwe or Haiti.

Assimilating Cultural/Social Factors into Drought-Hazard Reduction Programs. - Recent efforts to incorporate local knowledge and customs into water and agricultural development projects should be expanded, and drought-hazard programs should incorporate the lessons learned in other, sometimes inappropriate, resourcedevelopment projects. This applies equally in developed and developing countries. Public input to resource-development projects is required by law in some cases, but is becoming recognized simply as good practice elsewhere. Perhaps if drought planners will listen to what people want, the systems they provide will be better maintained and supported.

\section{A Final Note: Drought and Global Climate Change}

More than any other natural hazard attracting world attention under the IDNDR, drought offers the unique opportunity to link natural hazard reduction with concerns over global environmental change, especially climate warming. The International Geosphere/Biosphere Program (IGBP), also known as the "Global Change" research program, is addressing the potential for significant, human-induced changes in the global environment, while the UN's Intergovernmental Panel on Climate Change (IPCC) is examining the natural and social impacts of climate change and possible increases in drought frequency in a world warmed by enhanced greenhouse gases. Such programs should be linked to the IDNDR, perhaps using drought as a common concern. The value of such a coupling is that the rich literature of drought studies can offer insights into how societies might deal with climate change, while a better understanding of climate change will help define the potential for future droughts.

Many critical questions remain to be answered: Is the persistent drying of the African Sahel a signal of global warming or an extreme perturbation around a stable climate (Hare, 1987)? Is the hazard vulnerability exhibited by societies in transition from traditional to modern resource systems (for example, Kates. 1981) an inevitable concomitant to development, or can this "window of hazard vulnerability" be closed, even partially? Can successful drought-mitigation programs, such as those implemented in India (Sinha and others, 1987) or the southeastern USA (Riebsame and others, 1991), be transferred to other countries? Answers to such questions would not only help societies deal with drought, but make them more resilient in the face of climate change.

\section{References}

Aakre, D., Leholm, A., and Leistritz, L., 1988, Assessing the severity of the 1988 drought on North Dakota farms and the impact on the state's 
economy. Paper presented at the Drought Water Management Workshop, Nov, 1-2, 1988, Washington, DC.

Allan, R., and Heathcote, R.L., 1987, 1982-82 drought in Australia in Glantz. M. Katz, R., and Krenz. M. eds., The Societal Impacts Associated with the 1982-83 Worldwide Climate Anomalies: Boulder, CO: National Center for Atmospheric Research.

Diaz, H.F., Bradley, R.S., and Eischeid, J.K.. 1989, Precipitation fluctuations over global land areas since the late 1800s: Journal of Geophysical Research, v. 94, p. 1195-1210.

Garcia, R., 1981. Drought and Man: The 1972 Case History. Vol, 1. Oxford, Pergamon Press.

Glantz, M.H., eds., 1987, Drought and Hunger in Africa: Cambridge University Press.

Hare, F.K.. 1987, Drought and desiccation: twin hazards of a variable climate, in Wilhite, D.A., Easterling, W.E., and Wood, D.A., eds.. Planning for Drought: Toward a Reduction of Societal Vulnerability: Boulder, Colorado, Westview Press, p. 3-10.

Interagency Drought Policy Committee, 1988. The Drought of 1988. Final Report of the President's Interagency Drought Policy Committee: Washington, D.C., White House.

Kates, R.W., 1980, Climate and society: lessons from recent events: Weather, v. 35, January, p. 17-25.

Kates, R.W.. 1981, Drought in the Sahel: competing views as to what really happened in 1910-14 and 1968-74: Mazingira, v. 5, no. 2 , p. $72-83$.

Lamb. P.J., 1982, Persistence of Subsaharan drought: Nature, v, 299. p. $46-48$.

Liverman, D., 1990, Drought impacts in Mexico: climate, agriculture, technology, and land tenure in Sonora and Puebla: Annals of the Association of American Geographers, v. 80, p. 49-72.

Mitchell. J.K., 1989, Where might the International Decade for Natural Disaster Reduction concentrate its activities? A comparative analysis of disaster data sets: Boulder, Colorado, Decade of Disaster Reduction Discussion Paper No. 2. Natural Hazards Research and Applications Information Center.

National Academy of Sciences, 1987. Confronting Natural Disasters: An International Decade for Natural Disaster Reduction, Washington. D.C., National Academy Press.

National Water Council, 1977. The 1975-76 Drought: United Kingdom, London.

Riebsame, W.E., Diaz, H.F., Price, Moses, T. and Price, M., 1986. The social burden of weather and climate hazards: Bulletin of the American Meteorological Society, v, 67, p. 1378-1388.

Riebsame, W.E. Changnon, S.A.. and Karl, T.R., 1991. Drought and Natural Resources Management in the United States: Boulder, Colorado. Westview Press.

Rasmussen, E.M., 1987, Global climate change and variability: effects on drought and desertification in Africa in Glantz, M.H., ed., Drought and Hunger in Africa: Cambridge University Press, p. 3-22.
Sinha, S.H., Kailasanathan, and Vasistha, A.K., 1987, Drought management in India: steps toward eliminating famines in Wilhite, D.A., Easterling, W.E., and Wood, D.A., eds., Planning for Drought. Toward a Reduction of Societal Vulnerability, Boulder, Colorado. Westriew Press, p. 453-470.

Timberlake, L., 1985, Africa in Crisis, Washington, D.C., Earthsean.

Trenberth, K.E., Branstator, G.W., and Arkin, P.A., 1988, Origins of the 1988 North American drought: Science, v. 242, p. 1640-1645.

Wilhite, D.A., and Glantz, M.H., 1985, Understanding the drought phenomenon: the role of definitions: Water International, v. 10, p. 11-120.

Wilhite, D.A., Rosenberg, N.J., and Glantz, M.H., 1986. Improving federal response to drought: Journal of Climate and Applied Meteorology, v, 25, p, 332-342.

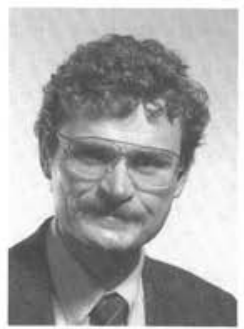

William Riebsame is director of the Natural Hazards Research and Applications Information Center at the University of Colorado. The Center was founded in 1976 as a national clearinghouse of information on the social and economic aspects of natural hazards and their mitigation. It provides information, referral, and library services to the U.S. hazards community, with a focus on translas. ing research into practical application.

Riebsame received his Ph.D. in geography from Clark University in 1981, where he studied farmers' responses to drought in the U.S. Great Plains. After teaching at the Univer. sity of Wyoming, he became director of the Natural Hazards Center in 1983. His expertise is in the impacts of weather and climate hazards, and social adaptation to environmental change. Recent research includes studies of the effects of climate change on water resources management and trends in hazard vulnerabil. ity in the U.S. 